\title{
Political Frustration, Trauma, and Self-therapy from Nature: Life and Freedom*
}

\begin{abstract}
Danqiong Zhu
Xidian University

When ancient Chinese literatus suffered political frustration, they generally experienced tremendous emotional and psychological traumas. These traumas are entangled with disappointment, anger, fear, grief, desolation, and other emotions. In most cases, the literatus would turn to nature for relaxation and freedom, composing a lot of literatures in an attempt to reflect on the meaning of life. In this paper, I will analyze the written works of Qu Yuan, the Seven Sages in the Bamboo Grove (竹林七賢), Liu Zongyuan, and Su Shi after they suffered political frustration to: (1) describe how their emotions changed; (2) illustrate how they built relationships between nature and self to relieve their frustrations; (3) clarify during these reflecting processes how they actually experienced the transformation and pursued the meaning of life; and (4) illuminate the significance of these pursuits, not only in spurring the boom of literal naturalism, but also in passing on the message for the current era with the joint crises of humans and the environment, to heal the earth and free themselves.
\end{abstract}

Keywords: trauma, ecotherapy, duality of life, meaning of life, freedom

\section{Introduction}

China's pollution is notorious throughout the global planet and there are more than 200 cancer villages in the whole country, covering from the east costal area further to the mid-west (Liu 2010). In China, people consider environmental degradation as a by-product of the country's industrialization and urbanization. Thus, we face exactly the same problem as western developed countries half a century ago. The implication behind this thinking is that China will be able to tackle this problem automatically, after it turns into a rich country with a booming economy. This may not be true, though. If we take a perspective of looking at the environmental history, the outstanding research of Mark Elvin (2004) shows us that through China's civilization, we don't change much, and the human-nature relationship was ruined centuries ago, similar to the contemporary period. It was in this context that I began to consider human-nature relationship in China's modern and historical period. This paper is one of the many endeavors in which I try to understand this relationship.

Today, to discuss psychological trauma, people will relate it to victims of the Nazi Holocaust, World War II veterans, Vietnam veterans, and all kinds of refugees from wars, flood disasters, earthquakes, tsunamis,

*Acknowledgements: In writing this paper, I would like to express my gratitude to the following people: Peter S. Wenz, Tih-Fin Ding, Jiyuan Yu, James Sellmann, Michael Slote, Frances Shen, Andrew Predmore, Hua Qin, Jennifer J. Manthei, Jonathan Goldbergbelle, Guanghua Fang, Yangju Xie, Si Qi, and Chen Yang.

Danqiong Zhu, Ph.D., associate professor, Department of Philosophy, Xidian University, China; main research field: Environmental Philosophy and Chinese Philosophy. Email: dqzhu22@xidian.edu.cn. 
and so on. Researchers will carry out empirical investigation on those survivors to study post-traumatic stress disorder (PTSD) and the recovery process. In contrast to empirical and positive research on these survivors in the 20th century, for three reasons those people who suffered from psychological traumas centuries ago and their recovery have been ignored.

First, since those people are dead, we have no way to observe, question, or design an experiment or interview them to know how they suffered from the catastrophe and how they reacted and recovered from them, if they did. Second, in psychological research and all other scientific researches, we consider that discovering models or patterns through enormous psychological and behavioral phenomenon is beneficial to pragmatically applying those models or patterns in future psychoanalyzing or a therapeutic process. Since we could get enough research materials from 20th century, why do we bother going back centuries ago to run after a shadow and make a seemingly ungrounded research? Third, the main streams of western psychotherapy, from Psychoanalytic therapy, to Adlerian, Existential, Person-centered, Gestalt, Behavioral, Feminist, Family systems, and Narrative therapy, all concentrate on human-human relationships, such as people and their childhood, people and self, people and their siblings, people and their parents, people and their counselors, and people and others. Those therapeutic principles and approaches begin with human-human relationships and end at that point as well. ${ }^{1}$

The above three could also be argued against with the following two points: Firstly come the research objects. Psychologically, we investigate living people. But for historical figures who suffered from traumas and recorded their psychological feeling, emotional waves, and their self-reflective processes in their odes, poems, and prose, should they and their works be treated as the objects of psychological research? Those people shared a common life similar to what we have today. Human in the 20th century may suffer from the holocaust, natural disasters, and war that people centuries ago also met. Slaughters, violence, imprisonment, pillage, and the dark side of human civilization are like the shadows of life. We faced and suffered similar problems throughout human civilization, from the jungle to a concrete jungle, from primitive tribes to modern societies. Human suffering is the pain of life itself. Life calls on freedom and alleviating the pain through human effort, especially for those people who continued to struggle against the pain of life. The historical figures discussed in this paper are fairly typical. In this paper, "trauma" refers to all the negative mental states they suffered. ${ }^{2}$ Secondly, although humans have long been the center in both psychological and therapeutic research, people as early as half a century ago realized that not only humans need to be healed, but also the planet is in a vulnerable state and needs to be saved or protected. The concern for preserving and conserving wild nature originated from environmentalism, after which anthropocentrism has been refuted. ${ }^{3}$ Theodore Roszak (1992) devised the term of "ecological unconscious" to demonstrate the purposeful continuity and unity in the ordered complexity of nature and human life. Human just cannot get happiness through a wounded and scarred earth with degraded forest, contaminated rivers and soil, and polluted air. But actually, earth, as a giant organism, as Gaia (Lovelock 1979), could recover itself from degradation, not in a human historical scale. This is a very simple truth. Humans have always been supported by nature, not only physically but also mentally.

In this paper, I will focus on the works of several Chinese sages who mentally suffered from political frustration, and describe their psychological process after the persecution. Then I will explore their therapeutic process from nature and then discuss what this means for human nature, life, freedom, and at last, the planet. 


\section{Political Frustration and Emotional Fluctuation}

The historical figures in this paper, Qu Yuan (343-278 BCE), the Seven Sages in the Bamboo Grove (竹林 七賢), Liu Zongyuan (773-819) and Su Shi (1037-1101) all suffered from political frustration.

\subsection{Qu Yuan’s Grief}

Qu Yuan, well-known in China and mostly regarded as a national hero, lived in an era known as Warring States, when the Kingdom of Qin ambitiously had the intention to unify the other six feudatory nations. As minister of King Huai of Chu, Qu Yuan tried to protect his nation from attack. However, King Huai of Chu did not accept his advice and eventually he was banished from the court to the South, a wild and savage place. In this paper, I focus on what happened after his banishment and before his suicide. What kind of emotional fluctuation could make him give up his own life?

His writings emanated intense loneliness and unresolvable grief. He believed that he was the only one who knew what was right for the kingdom of Chu. Suffered from his political career, he also deemed that none of the country could understand and accept him. At the beginning of Li Sao (On Encountering Trouble), he, a scion of the high lord of Gaoyang, noticed that time never stops for anyone, and the plants fade and fall with seasonal changes. Thus, human should ride on the limited time, positively, hopefully, and confidently to make himself a talented person who had the potential to bring benefit for his country. But a talented person could only accomplish his mission on condition that a wise monarch is in charge. Obviously wise monarchs refer to Yao and Shun, pure and perfect, who knew the right way for ruling a country. However, there was also the opposite way of running a country. Qu Yuan (David Hawkes 1985) wrote:

Glorious and great were those two, Yao and Shun, 彼堯舜之耿介兮,

Because they had kept their feet on the right path. 既遵道而得路。

And how great was the folly of Jie and Zhou, 何然紂之猖披兮,

Who hastened by crooked paths, and so came to grief. 夫唯捷徑以窘步。(69) ${ }^{4}$

Unfortunately, his king, King Huai of Chu, in view of Qu Yuan, surrounded by a group of fools, was not wise enough to keep the country going in the right direction. The King rejected Qu Yuan's ideas and instead adopted other officials' suggestions. What's more, Qu Yuan's encounter became a guide for any future fellow travelers through the centuries. Whenever there were officials suffering political frustration, there were injustice and malpractice in the politics of the day.

Therefore, Qu Yuan grieved for: First, the king was not so wise as ancient Yao and Shun so that the country fell into a trap set by the Kingdom of Qin; second, he would not imitate their behavior, would not be fouled or tainted by those people; thus, he was not able to fulfill his mission of saving the country. In Zhao Hun (Summons of the Soul), again he described himself in such words like, "pure and spotless," "imbued with unfailing righteousness," and living in a vicious world, "I have long been unfortunate and full of bitter sorrow" (David Hawkes 1985, 223). How did he describe his relationship with other "fools" and express his frustration?

Eagles do not flock like birds of lesser species; 驇鳥之不群兮,

So it has ever been since the olden time. 自前世而固然;

How can the round and square ever fit together? 何方圓之能周兮,

How can different ways of life ever reconciled? 夫孰異道而相安;

Yet humbling one's spirit and curbing one’s pride. 屈心而抑志兮, 
Bearing blame humbly and enduring insults. 忍尤而攮詬;

But keeping pure and spotless and dying in righteousness: 伏清白以死直兮,

Such conduct was greatly prized by the wise men of old. 固前聖之所厚。(71) ${ }^{5}$

This emotional state, not only for being unacceptable by the king and other officials, but even being rejected by the whole society because of his virtues, wrung his heart and brought a disappointed sigh at the end of the Li Sao:

Enough! 已矣哉,

There are no true men in the state, no one understands me. 國無人莫我知兮,

Why should I leave to the city of my birth? 又何懷乎故都;

Since none is worthy to work with in making good government, 既莫足與為美政兮,

I shall go and join Peng Xian in the place where he abides. 吾將從彭咸之所居。(78) ${ }^{6}$

Through the Li Sao, Qu Yuan fully expressed his patriotic feelings and his wishes of not compromising with the evil elements. After the Kingdom of Qin violated the treaty with Chu, King Huai of Chu recalled Qu Yuan back to the court. It is not the end of the story. More political challenges and turmoils awaited him. After King Huai of Chu died in Qin, the Kingdom of Chu once again was drawn into a dilemma between compromising with Qin and fighting against it. The destiny of the poetic politician did not change much. He was still the one traduced and rejected by his peers, the one assuming whole society had corrupted, and the one who was loyal, righteous, but deeply immersed in the grief.

Some sections of Jiu Zhang (Nine Pieces) were written during the period of King Xiang of Chu when Qu Yuan was banished the second time to the far south. In She Jiang (Crossing the River), he explained his destiny was just like those former loyal men unable to serve the country and he was doomed to struggle against adversity. Although he knew his own destiny would end in darkness, he would no longer complain his suffering but adhere to his own principles and live in the wild nature far away from the court. In Ai Ying (A Lament for Ying), the poet felt so sad about the homeless people and so worried about their incapability of getting back to Ying that in his heart "grief comes following sorrow and sorrow follows grief" (憂與愁其相接). In Chou Si (The Outpouring of Sad Thought), the poet wrote that (his) "pains grows only greater." Depressed, gloom, and sore afflicted, the poet found no way out and eventually chose to commit suicide. In Huai Sha (Embracing Sand), contrasting to the thriving summer, the poet decided to end the afflicted life. He wrote:

Let my heart calm and my mind at ease: why should I be afraid? 定心广志, 余何畏惧兮！

Yet still, in mounting sorrow and anguish, long I lament and sigh. 曾伤爰哀, 永叹喟兮。

For the world is muddy-witted; none can know me; the heart of man cannot be told. 世溷浊莫吾知, 人心不可谓兮。

I know that death cannot be avoided; therefore I will not grudge its coming. 知死不可让, 原勿爱兮。(172) ${ }^{7}$

About 278 BCE, Qu Yuan threw himself into Miluo River.

\subsection{The Seven Sages in the Bamboo Grove-Depression}

The Seven Sages in the Bamboo Grove symbolized a political life style in Chinese history, representing a particular attitude of those sages who were removed from political power. Far away from the court, they exerted invisible yet great influence on politics. Specifically to the seven persons in the group, they lived differently and thus ended with different fates. Although the term of "the Seven Sages in the Bamboo Grove”8 probably conveyed misleading information to people that they were similar in political standing, actually their 
differences had gotten closer attention than their similarities, especially in their different political attitudes. Guo Xiwei (1992) described their attitudes toward the Sima family, the usurper taking power from the young king of Wei, with three types, bender, hedger, and resister.

$\mathrm{Xi}$ Kang, refusing to cooperate with the Sima family, was a resister. Some distinctive characters, such as his tall and elegant figure, unique appearance, and aloof behavior, spread his renown. His friend, Shan Tao, commented, “As a person, Xi Kang is majestically towering, like a solitary pine tree standing alone. But when he’s drunk, he leans crazily like a jade mountain about to collapse” (Minford and Lau 2000, 457) (嵇叔夜之為 人也, 岩岩若孤松之獨立; 其醉也, 傀俄若玉山之將崩). This remarkable manner did not change when he was killed in 262, for that he even played the Melody of Guangling before the execution. In the letter to Shan Tao (《與山巨源書》), quite frankly, he refused to be the successor of Shan Tao in the court.

As a fully upright scholar, Xi Kang failed in the endeavor to pursue justice for Lü An whose wife was seduced by his brother and ended up with imprisonment. Then he wrote A Song of Disillusionment (幽愤诗), in which he realized his misery was a fabricated charge. In this poem, he reflected his juvenile period that sculptured his self-indulgent character formed, which again implied he had no interest in dealing with sophisticated interpersonal relationship in the political arena but only strong desire for Dao. After being put into prison, he was surely worried that the secular affairs would disturb his inner peace.

During his imprisonment, Xi Kang was in a very emotional state. He felt so denigrated that even jumping into the clean water could not purify him. Although he was right and honesty, his spirit was enduring insults (雖 曰義直, 神辱志沮). His painful experience drove him to imaginatively escape from society to wild nature (采 薇山阿, 散發岩岫). ${ }^{9}$ Gone wild was refused by the ruler and the poet was killed. The far-reaching political implication of the whole case soon emerged: Before the execution, three thousand students from the government's school went to the execution place, petitioning Xi Kang to be their teacher.

Initially Ruan Ji was also a resister. His gloomy mood was described as “rough and rugged terrain” (胸中 壘塊) (Minford and Lau 2000, 450), and “that’s why he needed wine to irrigate it” (故須酒澆之) (Minford and Lau 2000, 450). He composed 82 "Poems of My Heart” to convey his depressed feelings. Two of the poems were like this:

Being sleepless at midnight, I rise to play the lute. 夜中不能寐, 起坐彈鳴琴。

The moon is visible through the curtains, and a gentle breeze sways the cord of my robe. 薄帷鑒明月, 清風吹我襟。

A lonely wild-goose cries in the wildness, and is echoed by a bird in the woods. 孤鴻號外野, 翔鳥鳴北林。

As it circles, it gazes. At me, alone, imbued with sadness. 徘徊將何見,憂思獨傷心. (Minford and Lau 2000, 451) ${ }^{10}$

Day and night revolve. 一日複一夕, 一夕複一朝。

While my face wrinkles, and my spirit wanes. 顏色改平常, 精神自損消。

But the sight of injustice still pains me. One change induces another. 胸中懷湯火, 變化故相招。

That can not be dealt with by tact or wit. The cycle goes on forever. 萬事無窮極, 知謀苦不饒。

I only feel that in a moment, life will disperse in the wind. 但恐須头間, 魂氣隨風飄。

I have always trodden on thin ice. Yet no one knows! 終身履薄冰, 誰知我心焦! (453) ${ }^{11}$

In these two poems, the poet felt life was short and fragile. It was probably because of this fragility that Ruan Ji at last surrendered to injustice and evil forces. He felt nobody could understand his loneliness just as Qu Yuan did, and he produced more poems than Xi Kang to express the frustration and depression. 


\subsection{Liu Zongyuan-Desolation}

As a main figure of the Gu Wen Prose reform, Liu Zongyuan (773-819) was also a member of the vulnerable political community known as the Wang Shuwen reforming group. All of the reformists were banished due to the failure of the reform which resulted in the affair of “2 Wang 8 Sima (二王八司馬)” after the new emperor succeeded to the crown. Jo-shui Chen (1992) pointed out the "Wang clique acted much like an antiestablishment party in modern democratic or revolutionary politics” (75).

Liu Zongyuan was banished thousands of miles away from the capital at Chang'an in faraway south to Yongzhou, and arrived there at the end of 805. Before the reform, he was a young man passionate about serving the country, with great ambition for a political career. After being in exile for ten more years, his ambition faded away. Chen thought Liu Zongyuan was turned "from a man of action into a man of ideas" (189). To emphasize his psychological trauma, I would rather suggest that he was turned from a bold patriot into a desolate man. This transformation was typically described in his poems Eagle in a Cage (笼鹰词) and Mourn on Plight (感遇).

In the first half of Eagle in a Cage, he depicted an eagle cleaving the sky, attacking other animals and birds at remarkably high speed, and hanging fur and feather of the weaker on its sharp talon after a violent battle. The eagle, as a winner of the battle, scared all other birds and animals away and looked around the wilderness like a hero. While in the latter half, the winner and the hero was captured and chained in a cage to epilate its feather, without which the hero crumbled. All other little animals like racoon dogs and rats began to make fun of him, but the hero still looked around, not in the manner of bravery or heroism though, but of fright, shock, and horror (一夕十顧驚且傷) (Liu 1979, 1246). It was in Mourn on Plight that this transformation of his attitude completed.

At the beginning, the jackdaws fly on the wild grassland in the sunlight, 旭日照寒野, 㦛斯起蒿萊。

And chirp merrily at the foot of West Mountain. 啁啾有餘樂, 飛舞西陵隈。

Very soon when the winter comes, leaves float down to the ground and the land is left bare. 回風旦夕至, 零葉委陳荄。

Jackdaws have no place to hide and what is waiting for them are the falcons and hawks. 所棲不足恃, 鷹隼縱横來。(Liu 1979, 1255).

In the Eagle in a Cage, he was the eagle, for a time was a hero, a reformist, who was although suppressed but could wait for the chance to return to battle. In Mourn on Plight, he realized he was just a prey, having to face a frightening life all the time. On the way to Yongzhou, he wrote Mourning Qu Yuan (吊屈原文) to praise Qu Yuan for sticking to his own principle uncompromising to dishonorable force.

During those 10 years living in Yongzhou, Liu Zongyuan was frequented by desolation and grief. Those old officials would not write back to his letters. I sometimes wonder whether this was particular to Chinese culture at that time or universal to human beings independent of cultural difference. Once a person made mistakes in his/her political career, he/she, rejected by peers, would fall into an intensely miserable living condition. They even could refuse to help the weak while talking about morality. Are these glories of human nature? Fellow peers refused to help, and what Liu could do was just staying at the faraway south where there were few sages he could talk to. His deep desolation was conveyed by the most cited River Snow (江雪), which says:

A hundred mountains and no birds, 千山鳥飛絕,

A thousand paths without a footprint. 萬徑人蹤滅。 
A little boat, a bamboo cloak, 孤舟䒾笠翁,

An old man fishing in the cold river-snow. 獨釣寒江雪。(Liu 1979, 1221)

This poem unwrapped a scroll in front of us, a man sitting in solitude and fishing in a soundless vast world. The poet kept the fishing man's attitude and mind hidden. Whoever could picture the painting on the scroll, he/she would feel his loneliness in the landscape.

\subsection{Su Shi-Death of Will}

Two hundred years later, another literary giant was born and was destined to be a master for his political situation. Unlike Liu Zongyuan, Su Shi moved a lot during his political career. He lived in Chang'an, Hangzhou, Mizhou, Huzhou, Huangzhou, Huizhou, and Danzhou, all the way from the capital, to Zhejiang province and Shandong province in east China, to Hubei province in middle south China, to further south Guangdong province, and last to the farthest south Hainan province. During those migrations, Su Shi floated further and further away from the capital, the center of China, which was the symbol of power in Chinese culture.

In Huzhou, Su Shi's poems were accused of opposing to Wang Anshi Reform. The prospective poet was put into prison, where he was afflicted physically and mentally for four months. In Write to Ziyou in Prison (獄 中寄子由), he told his brother that subjected to physical and mental torture, he almost died from abuse inflicted by the prison guard, "I dream in a cloudy mountain, my heart beats like deer's leaping, I was scared out of my wits and felt my life was fragile as a chicken in a kitchen” (夢繞雲山心似鹿, 魂飛湯火命如雞) (Su 1982, 998). Su Shi waited, trembling in fear, and at the end of "Wutai Poem Case" was banished to Huangzhou. When his brother assessed his writings after this banishment, "he changed his writing style, like a horse running on the boundless grassland, as a result his creation was like a river pouring down, and apparently I was not able to come up with him” (馳騁翰墨, 其文一變, 如川之方至, 而轍瞠然不能及矣) (Su 1982, 2813).

Living in a different place out of prison, Su Shi realized his life had been changed by his political experience. Similar to Liu Zongyuan, he admitted himself to be an offender of social order and mostly stayed with himself. This desolation was in full view in Song of Divination-Written at Dinghui Abbey in Huangzhou ( 卜算子·黃州定惠院寓居作).

From a sparse plane tree hangs the waning moon. The waterclock is still and hushed is man. 缺月掛疏桐, 漏衒人初靜。 Who sees a hermit pacing up and down alone? Is it the shadow of a fugitive swan? 時見幽人獨往來, 縹紗孤鴻影。

Startled, he turns his head, with a grief none behold. 驚起卻回頭, 有恨無人省。

Looking all over, he won’t perch on branches dead. But on the lonely sandbank cold. 揀盡寒枝不肯棲, 寂寞沙洲冷。(Su 2007, 171)

The fugitive man in this poem was even doomed to plunge into grief, not attempting to avoid persecution. He can only wander in the stillness of night and indulge in stricken distress. This distress and desolation promoted him to become a brilliant literary master. During the entire exile, he first expected to return to the north but time only gave him a mournful sigh. We could learn from the Moon on the West River (西江月) that he waited all his life to be allowed to return to the north, his hometown.

Like dreams pass world affairs untold. How many autumns in our life are cold? 世事一場大夢，人生幾度秋涼?

My corridor is loud with wind-blown leaves at night. See my brows frown and hair turn white! 夜來風葉已鳴廊, 看取眉 頭鬢上。 
Of my poor wine, few guests are proud. The bright moon is oft veiled in clouds. 酒賤常愁客少，月明多被雲妨。 Who would enjoy with me the mid-autumn moon lonely? Wine cup in hand, northward I looked only. 中秋誰與共孤光, 把盏淒然北望。(Su 2007, 145)

At the age of 62, Su Shi was banished to the extreme south. Two years later, he was finally permitted to return to the north. On his way back, he passed by a temple; inside he saw a picture of himself painted years ago, then he wrote some words: "My mind is dead like a fallen log, my body is like an untied boat. If you ask me my lifetime’s achievement, Huangzhou, Huizhou, Danzhou ” (心似已灰之木，身如不系之舟。問汝平生 功業, 黃州、惠州、儋州) (Su 1982, 2641). These three places mentioned are exactly his banishment areas where he suffered political frustration and spiritual torture. Through these words, he expressed who he was and totally denied the first half of his life of serving as a successful official.

\section{Self-healing Processes}

From the above narration, we could see those people share four common features: (1) their literary writings were all related to their political frustration to a certain extent; (2) through these literary writings they conveyed information about their mental activity or psychological process; and (3) apparently those people all experienced negative emotions, such as grief, desolation, and depression, one of whom even committed suicide. In this part, I will explore the fourth feature, which emerged after they suffered from political frustration; they attempted to find some peace by indulging themselves in nature. ${ }^{12}$ My question in this part is, through these self-healing processes, were they eventually healed? Or to what extent were they healed? How can we know those sages have been healed by nature?

In realistic therapy, although it is a bit difficult for patients and counselors to decide whether they have achieved the psychotherapeutic goals and when they should terminate the treatment, every therapy actually has an end. No matter how long a client receives counseling from a counselor, finally one day he/she has to bid to farewell to the therapeutic relationship. A few scholars still try to establish some minimal standard for the termination of psychotherapy. We can consult these criteria to decide whether those people above have been healed. For example, Irving B. Weiner and Robert F. Bornstein (2009) mention three minimum criteria for considering termination, viz., substantial progress toward the goals of the treatment, the patients' capacity to continue to observe and learn about themselves, and substantial resolution of the transference (285-286). The problem is, are there any, or should there be any standards for termination, as Estelle Shane asks? Based on large amount of literature and her experiences, Shane (2009) concludes that "it is impossible to create linear analytic goals or criteria for termination in the complexity of a nonlinear world" (173). The paradox between a certain method and an uncertain world, or the tension between therapeutic means and dynamic end places psychotherapy and its termination is a dilemma, making self therapy necessary for human life.

As a result, I will not adopt the standard principle to assess the consequence of the self-healing processes, but stress what Shane calls "individualistic and idiosyncratic nature of any psychoanalytic process" (168), which in this paper refers to the process that the above sages, particularly, independently, and spontaneously meditated on nature and obtains inspiration from it. Among the above sages, two people died directly of political frustration, Qu Yuan and Xi Kang. However, they differed from each other in a way. As for Qu Yuan, he chose suicide as the end. Xi Kang was killed by the persecutor. Suicide and persecution are totally different, as the former behavior is conducted by the subject and decided by one's own attitude and will, while the latter is a behavior toward the subject conducted by others regardless of one's own attitude and will. 
According to this difference, I could not judge whether Qu Yuan had been healed from nature. ${ }^{13}$ In Summon of the Souls (招魂), he praised the glory of his own country as the center, and every other country surrounding the center, as uncivilized, uncultivated, and uninhibited wilderness. For instance, he described the west as "red ants as huge as elephants and wasps as big as gourds. The five grains do not grow there; dry stalks are the only food” (Qu 1985, 225) (赤蟻若象, 玄蜂若壶些。五穀不生, 藂菅是食些). Nature, in the view of Qu Yuan, was not a home for his soul, but only the Kingdom of Chu was. That is why he could not be healed by nature. Another reason why he could not be healed by nature was that nature was only a subjective representation of his internal feelings. Nature was not nature itself which can enrich a person to be capable of a better understanding of his life, but nature, including all the plants and animals, was divided into two parts ${ }^{14}$ - good part with virtue and bad part with evil—based on his own political experiences and his frustration. In other words, I suggested that he could not be healed, because he did not even have the intention to be healed. He decided to die for his faith and principle, which meant he defended human dignity at the sacrifice of his life.

As for $\mathrm{Xi}$ Kang and Ruan Ji, they escaped to the bamboo grove, indulging themselves in drinking and “pure talk” (清談) to be free of injustice. They stuck to their own honor by not succumbing to those people in power. The typical teaching from them, “transcending the Confucian ethical codes and following nature” (越名 教而任自然) (The Editorial Committee of Chinese Civilization 2007, 356), encourages people to listen to the voice coming from within, follow their own inclination, and free themselves from the external Confucian rules. These callings originated from meditation of their pioneers as well as themselves. Through meditation, they realized there were what the spontaneous flow of nature required them and that human beings should live a life to pursue the truth that any political power or any other secular success could not surpass. Thus, they did not need to die directly for their faith and honor, but the reality only went to the opposite.

Through meditation, they reoriented their life and enriched it with new meaning. Their attitude actually decided their behavior. They gained a lot of consolation from bamboo grove, marked by their distinctive behaviors. For example, Xi Kang pretended to be busy with forging metal as if there were no one present when Zhong Hui paid a visit to him (Minford and Lau 2000, 457). When Ruan Ji was frequently drunk, he would sleep by the side of his neighbor's wife, under whose husband's careful observation, there was nothing amiss (450). Through these behaviors, they put their philosophy into practice. What was obviously expressed was not to control life, but to live a life in a way following the truth, or Daoism. Even when Xi Kang's life was about to be taken by those people in power, he did nothing to resist, only playing his music "Melody of Guangling" before the execution.

As for Liu Zongyuan, after 10 years' living far away from the center of political power, his view of life changed significantly. In Jo-shui Chen's research, he mentioned that nature had a psychotherapeutic function in Liu Zongyuan's life, "Liu often treated nature as an object to which he gave vent to his presentment and distress. Through essays, poems, and sometimes, perhaps, pure imagination, he talked to nature. He shifted to nature some of his burden and pains; silent and seemingly generous, nature could not but listen and accept” (183).

Chen also proved Liu Zongyuan frequently regretted about his ideas about reform and other measures to change the country, but Chen treated his regret as a self-protective philosophy, "the survival and satisfactory preservation of the self were the supreme values for a human being in a complex and perilous world" (168). Besides political frustration, what brought this change into the poet's personal world, to turn him from an official who devoted himself to the value of a society to a person who pursued the value of self? Many scholars 
would indicate that the previous official was guided by Confucianism, which encouraged people to be involved in social life, while the latter person was guided by Buddhism or Daoism that asked people to be concerned about their spiritual world. Well, the problem is, without nature, whether those poets and sages could make this change possible.

So far, it seems not so clear whether without nature they could heal themselves and make change come true, which I will demonstrate more explicitly through Su Shi's life experiences. Su's gift at describing all kinds of natural scenery can be found in his experiences in Hangzhou, a city of pretty city gardens and parks, and Danzhou, a city of wilderness. In his brilliant literature, nature was classified into several types. It could be as unique and magnificent as Qiantang Tide, whose beauty aroused his appreciation. It could be as tough and harsh as Mizhou which rendered his daringness to his epic works. It also could be any natural beauty in which the poet indulged himself and through which he gained a profound insight into the meaning of life. Different natural landscapes brought him different spiritual enlightenment which always helped enrich his understanding on human life (Zhu and Li 2011).

Furthermore, most scholars agree that Su Shi was healed eventually from political frustration. Zhu Jinghua (1996) believes that especially after the banishment of exile to Guangdong and Hainan, the poet buried his old ego, the one sticking to the secular world, abandoned political career, broke the shackles of social boundary, treated life itself instead of secular success as the end, and eventually achieved and enjoyed spiritual freedom by living a life in a way like heaven and earth (34). Ge Xiaoyin (1995) traces the development of landscape literature and concludes that Su Shi eventually found the fundamental truth of human life, which was embedded in human's relation to nature, revealed by the fact that human could always get inspiration from nature and live a pleasantly comfortable life in wild nature. Andrew L. March (1966) also reasons that Su Shi at last believed in the harmony of man and natural beauty, "what the landscape does is art; and is in turn the standard of true human conduct, the way one should go about emptying the container" (385). Through the above three comments, we could infer that Su Shi got a new idea on how human should live and thus healed himself by communing with himself with nature.

It is inconceivable that whether Su Shi would accomplish the healing process without emotionally attaching himself to the landscape, or to natural beauty, which is beyond landscape. ${ }^{15}$ By learning from heaven, earth, and landscape, he injected a new meaning to life. If there was anyone among all these sages who actually were hurt by political frustration and healed by nature, Su Shi would definitely stand out. The essence of this healing lies in the fact that he succeeds in changing his view on life and finding a new way of self-realization. To be specific, he, before the political frustration, associated self-realization with a successful political career, which centered on being a popular sage who would bring benefits to his people, and later, after political mayhem, switched to spiritual freedom to live in a way as nature does. One difference between Qu Yuan and Su Shi is that the former did not finally make the recovery from nature, while Su Shi did. Those other sages in this paper were between the two ends and they varied on the degree of healing effect.

\section{Duality of Life and Freedom}

In order to prove the inherent connection between nature and human life and nature's universal psychotherapeutic function independent of culture as well, I find some literature works by western writers, who after suffering from political frustration or any other sort of trauma, were healed by nature. Two points here inspire me. One inspiration is a Christian gospel song, written by Peter Scholte in 1966, "We are one in the 
spirit," and another is one of the basic teachings from Chinese philosophy, "Benevolence, righteousness, decorum, and wisdom are not conferred on me by others, I certainly have them” (仁義禮智, 非由外鋢我也, 我固有之也) (Zhao Zhentao et al. 1999, 251). ${ }^{16}$ Apparently, the Christian culture of original sin gives a different explanation to the human nature from Chinese Confucianism, which stresses on the positive characters inherent in all Humans. No matter how different their explanations to human nature are, at least they agree on there IS a human nature. If there IS, then what is that "IS?" I try to use the duality of life to answer this question.

First, I did notice there were some similar western literatures which recorded people's feeling after frustration and how happy they felt when exposed to nature. Typically, in the beginning of Reveries of the Solitary Walker, I found Jean-Jacques Rousseau (2011) was in a situation very much like those Chinese sages above:

So here I am, all alone on this earth, with no brother, neighbour, or friend, and no company but my own.

The most sociable and loving of human beings has by common consent been banished by the rest of society.

In the refinement of their hatred they have continued to seek out the cruelest forms of torture for my sensitive soul,

And they have brutally severed all the ties which bound me to them. (1)

It is such a big question that I could hardly explore the reasons why he had been in such a solitary condition. Here I just want to compare Rousseau's feeling after being rejected by the entire society with that of Chinese sages. On the one hand, Rousseau described these conflicting perceptions of loving human beings while at the same time feeling exhausted physically and mentally in society. On the other hand, he also depicted how he was absorbed in botany and how peaceful his mind was when he recalled the silence of grassland, river, woods, and field. I will cite the whole long passage which promoted my awareness and understanding of the question mentioned at the beginning of this part.

But if there is a state that where the soul can find a position solid enough to allow it to remain there entirely and gather together its whole being, without needing to recall the past or encroach upon the future, where time is nothing to it, where the present lasts forever, albeit imperceptibly, and giving no sign of its passing, with no other feeling of deprivation or enjoyment, pleasure or pain, desire or fear than simply that of our existence, a feeling that completely fills our souls; as long as this state lasts, the person who is in it can call himself happy, not with an imperfect, poor, and relative happiness, as one finds in the pleasures of life, but with a sufficient, perfect, and full happiness, which leaves in soul no void needing to be filled. Such is the state in which I often found myself on the Île de St Pierre in my solitary reveries, whether I was lying in my boat as it drifted wherever the water took it, or sitting on the banks of the choppy lake, or elsewhere beside a beautiful river or a stream gurgling over stones (55).

Besides Rousseau's personal experience, there is also some scientific evidence showing the impact of being cut off from nature (Though in the introduction part that I methodologically challenge science, it does not mean I reject it). Richard Louv (2005) proposes the concept of "Nature-Deficit Disorder” to define a common phenomenon in urban-industrial civilization, "the human costs alienation from nature, among them: diminished use of the senses, attention difficulties, and higher rates of physical and emotional illnesses" (36). It is not so difficult for us to get further scientific evidence empirically supporting an undeniable truth that human life can not live well without nature. Robert Greenway (Roszak et al. 1995) has conducted research for many years to identify the cultural essence of environmental crisis. He investigated thousands of people, collected 
questionnaires, did interviews and longitudinal studies, and gathered personal responses to get statistic information on "Wilderness effect," which showed 77\% described a major change after spending time on wild nature, possibly in personal relationship, employment, housing, or life-style (129).

What theory could be used to explain this particular phenomenon of healing human-community-generated hurt by nature? Why did Rousseau feel complete peace and happiness in nature? Why did those Chinese sages feel better in the boundless landscape? Why do people begin to change their attitude toward life after returning from wild nature? Why does nature have psychotherapeutic function?

Robert Greenway described "wilderness effect” as "feelings of expansion or reconnection," or "expansion of self" and "reconnection with adaptions of our evolutionary past." Since it is "reconnection," there must be a connection before. Paul Shepard, after tracing the development of human civilization, blamed the watershed of human being's hostility toward nature on invention of agriculture, before which "ontogenic crippling” human and nature were in harmony, while after which human beings were separated from nature by mistake just like a child separated from his mother (Roszak et al. 1995, 24). Theodore Roszak also mentioned the deep emotional connection between psyche and Gaia to reveal the essence of his "ecological unconscious” (Roszak et al. 1995, 15). Ralph Metzner used "pathological alienation" to define the split between human and the rest part of nature (Roszak et al. 1995, 55).

Obviously, we, modern people, are not the only generation reflecting on the wrong direction of whole human civilization. If we ask Chinese ancient sages why and how we could be healed through nature, they would answer "it is just the way we are," by following nature’s way, they achieve Dao. ${ }^{17}$ Dao is the starting point when human and nature are connected and finally merged as ONE. According to Laozi, "Thus the loss of the Way, Meant the advent of virtue, The loss of virtue, The advent of kindness, The loss of kindness, The advent of service, The loss of service, The advent of ritual rule. Ritual rule turned loyal trust to deceit, Leading to disorder” (Laozi 2004, 106) (故失道而後德, 失德而後仁, 失仁而後义, 失义而後礼。夫礼者忠信之薄 而乱之首). This explains how Laozi considered the establishment of human civilization, the development of ethical rules, and the construction of social order were split from the Way. Eventually we could see east and west meet together regarding the origin of human life.

Since to a certain extent, both east and west view human civilization as the fundamental divergence between human and the rest of nature, can we simply go back to the starting point to save the planet, just as many backpackers and explorers did? In 1992, a 24-year-old Californian named Christopher McCandless was found dead of starvation after 4-month's wild hiking into Alaskan wilderness. ${ }^{18}$ In 2009, Ed Wardle was scheduled to spend three months alone in the Tincup Lake area to film a documentary series entitled Alone in the Wild, but he quit and asked for rescue after seven weeks. ${ }^{19}$ At the end of the experiment, the man said "the wild does not care if I am ill or not, and if I have enough food or not. It does not care if I am lonely. It does not care if I am so miserable. The wild is just here. It's the wild.” In the beginning, nature is the home. People want to go back home, but home has become a home they could never return any more.

Thus, here is the situation: We put ourselves into a familiar dilemma. It is familiar that we have always been worried about this split. And the dilemma is, on the one hand, optimistically and hopefully Paul Shepard says, "An ecologically harmonious sense of self and world is not the outcome of rational choice. It is the inherent possession of everyone; it is latent in the organism and in the interaction of genome and early experience" (Roszak et al. 1995, 39). On the other hand, as a matter of fact, those who tried to return to the wild 
nature ended up with tragedy, only found themselves hurt both physically and mentally, feeling even more deeply separated from nature and difficult to return to culture and society.

For no other reason than this dilemma did we again and again observe the divergence of our behavior from nature. In western tradition, it was fear and hostage toward wilderness and it brought flourishing urban-industrial civilization. It was also the conflict, contrast, and even opposition between America's agriculture, forestry, and fishery that as Aldo Leopold (2001) wrote, "the same basic paradoxes"- “man the conqueror versus man the biotic citizen; science the sharpener of his sword versus science the search-light on his universe; land the slave and servant versus land the collective organism" (187) — they were conflicting elements inside the attitude and behavior toward nature. In eastern tradition, it was the paradox of those frustrated sages throughout ages that who escaped to wild nature in pursuit of meaning of life and healing of themselves. They, never totally loaded off the burden of social civilization, only individually obtained spiritual freedom of human as a species completely different from other lives, though. In contemporary China, it is the paradox between the fact that urbanization is swallowing the land, wetland, forest, and even ocean, and the fact that planers attempt to transplant nature into cities by emigrating ancient woods into city parks and building artificial ecological wetland in outskirts.

As Holmes Rolston (1989) wrote, “there can be no single self, for consciousness is social” (227). Thus, in his view, "I but apparently escape and am trailed by memories and public education. A person's flight to nature is always artificial, for that our specific essence is indissolubly a corporate humaneness" (227). From this perspective, even when a person comes to wilderness, he/she is not a pure individual, but a peculiar culturally or socially bounded person. Without the heavy burden of being a human or even being a concrete individual, he/she could not give birth to such complicated feeling. Specifically, for those Chinese sages, without their political frustration, their emotions would not wave in the way they actually did, the natural scenery would not urge them to meditate on the meaning of life, and also it is hard to tell whether the brilliant naturalism would finally come into being.

Probably we could sum duality of life in this way, psychologically and ecologically, there is a paradox between ecological self which was determined by ecological unconscious, calling human to return to wilderness, and social or cultural self, both determined by history, politics, by all kinds of human relationships, by human-nature relationship on condition that he/she happens to be an environmentalist, and his/her whole unique life experience. Common to all human beings, the ecological self was for most of people covered by social or cultural self. When the social and cultural self pursues self-actualization and succeeds, it is difficult for the ecological self to reveal itself. In some cases even those people who have secured a success in businesses or other fields need a backpack to wild nature. To take it further, when people's self-actualization is hindered, the ecological self will come out and perform its function to change a person's attitude and behavior to realize other potentials. This duality of human life is not only the paradox between life and death, between potentiality and actualization, between a pure living being and a socialized individual, but between an individual out of nature and a member of human civilization carrying on all his/her living experience. This duality also brings some implication to our understanding of freedom.

The above Chinese sages represented a four-generation or four-stage process through which human beings built therapeutic relationship with nature, from spontaneously to consciously. It turned out to be a gradual process with improved therapeutic effect. Individually, Su Shi's survival represented the biggest success of natural healing, which only came at the sacrifice of a regression of society, in that the better one survives, the 
more he sacrifices. However, due to the specificity of political frustration from other psychological problems, I could not tell whether the four-generation process was all good to human life. In Confucian tradition, scholars were encouraged to be officials, and sages were inspired to cultivate themselves to regulate their families, govern rightly their states, and eventually bring peace to world; the consequence of successful therapy from political frustration was merely the fact that individuals were more and more inclined to surrender to political authority to give up effort to change or transform a society, and progressively submit to historical determinism.

The effect of this phenomenon could be explained by the tragedies of two sages living at same era-Ruan Ji and Xi Kang. Ruan Ji was much more depressed than Xi Kang, because while Xi Kang, adhering to his own ideal and his indomitable spirit, was executed, Ruan Ji survived at the cost of his own dignity. When assessing the different destiny of Xi Kang and Ruan Ji, Guo Xiwei (1992) pointed out that the death of Xi Kang was a demonstration that the scholars with critical opinion on society and independent personality were unacceptable by temporal feudal system. Surely the persecution of Ji Kang was a tragedy, but the tragedy of Ruan Ji, forced to surrender himself to the usurper, was even more experienced, which bears a more profound meaning. It represented that the moral integrity of Ruan $\mathrm{Ji}$ and many other scholars had been split apart with their independent spirituality worn away. As for the one who was not healed at all, Qu Yuan, his suicide proclaimed the indomitability of free will. That is the big difference between political frustration and other common psychological inhibition. He just could not recover from but died of the emotional and psychological trauma. Without this sacrificial death representing the dark side of human history, the glory of human nature could not be manifested.

But what did what we call human civilization do to this sacrifice? Down throughout the centuries, the point that Chinese sages survived better during political frustration with more successful self-healing experience, and yet this improvement in individual's healing was not from human community but from nature, actually strengthened the authority of political power and had an intense implication to individuals that the only freedom that could be attained was the spiritual freedom, and the right that one could metaphysically think about the meaning of life and change one's own behavior for growth. Psychologically, it is a positive thing which we call resilience, or in Darwinian term, evolution of psyche. Politically, it is a vision of degradation that individuals increasingly surrendered to powerful political authority, and this vision produced the current common acute inequality among all kinds of political systems, expressed as a form of deep gap between elites and civilians, even the capability and condition variance among different classes to make effort for personal achievement.

Now it seems that freedom, the most valuable thing, is cultural. ${ }^{20}$ Chinese traditional culture, collectively and mentally rooted in Chinese people, fostered a different understanding of freedom. It is not the same as the freedom, which is cultivated through western civilization, is marked with right and obligation, and built on reason, human equality, and out of monotheism. This freedom believes there is only one omnipotent God and all humans are equal but no other human can be as same as the Father excepts the Son. While in Chinese tradition, it is natural theology. God's law is in nature, and human can learn from nature to get information from God, regulate oneself, and build an ideal society following nature's way. Consequently, Confucianism learns from nature (heaven and earth) raising all creatures like parents nursing their children, and instructs Chinese monarchs and sages, who call people "Zimin," to be imitative of nature's way to breed people; Taoism learns 
from nature in achieving everything by doing nothing purposely and exhorts governing class to follow the "Way" nature does.

Nature has an ecologically hierarchical structure with heaven and earth or their law at the top, human and all other creatures staying in a stable state as a whole, while in a flowing state as an individual. The freedom in Chinese tradition was to make change happen when in power, and escape from society to nature when out of power. We can call this "psychological freedom," as May (1962) states "Freedom is something you grow into" (46). This psycho-understanding of freedom can be used to explain why Su Shi, the fourth-generation, wrote “From now on, I would vanish with my little boat, for the rest of my life, on the sea I would float” (小舟從此逝, 江 海寄餘生) (Su 2007, 169). Thus for those frustrated sages, freedom is not in society, but among natural beauty, in nature itself. Freedom is to surrender. For the sake of the larger community, they responsibly and consciously escape. This also can be used to explain when it comes to the issues of freedom and democracy in a western sense, the popular ambivalence exists among contemporary Chinese intellectuals, either considering that the current society is not ready for them yet, or believing the east can develop another system of freedom, and democracy in which they will be used as instrument to achieve a higher good and an evolution of a greater community. As the saying goes, if you cannot change the world, change yourself.

Therefore, west and east are culturally divergent, but can be convergent eco-psychologically. Hopefully, they will meet in nature where all cultural difference fade, appreciating the circle of life, the beauty of the planet, and the dignity of life. The convergence is our hope for a healthier planet. The planet is in the long run that the greatest community and its health require us to work together. Since the split between human and nature is one of the major roots of the environmental crisis, it is time for us to go beyond the limits of urban-industrial civilization and build a new ecological civilization. For the developing countries which have followed developed countries' steps to industrialize and urbanize, especially China, we need to free ourselves from material prosperity, being aware that we have the choice to establish a good relationship with nature. However, I suggest the approaches be inside our established civilization, not in the faraway wilderness. As for wilderness, leave it alone and keep it intact if there is any left. That is, we need to build some transitional areas between cities and pure wilderness for human therapy and preserve some pure wilderness as therapy for the planet.

\section{Conclusion}

In summary, the four-generation Chinese sages who suffered from political frustration experienced apparent negative emotions, such as grief, depression, desolation, and death of will. After the frustration and persecution, they spontaneously or consciously turned to nature for healing and recovering. According to their intention, they were respectively healed to varying extents. The most successful healing experience came after the person finished personal transformation and changed his perspective on the purpose of life by letting landscape or nature come into his life. In contrast to those who view the transformation as developing from Confucianism to Taoism or Buddhism, I argue that without landscape or nature, they could not finish the processes.

Those sages' struggling reveals the duality of human life and the conflict between two kinds of self, the ecological self and social or cultural self. Those Chinese sages follow the ecological self to pursue psychological freedom and feel inclined to surrender under political authority. The freedom built on the ecological self is different from the freedom in the western sense that is developed from the cultural self which treated reason, equality, right, and obligation as important concepts. The ecological self is common to all 
human beings whether they are from west or east. That is the calling from the earth, asking human beings to go forward hand in hand. Heal ourselves and heal the planet. Save the planet and free ourselves.

\section{Notes}

1. Surely this is not true for those pioneers who practice environmentally related therapeutic skills, such as Michael J. Cohen's "living organism," Steven Harper’s “wilderness therapy” and Sarah A. Conn’s concept of "materialistic disorder," and so on. But compared to enormous members of the main stream in psychotherapy, they are quite few. For the practice of those relatively few nature-therapy, see Martin Milton, waking up to nature: exploring a new direction for psychological practice, Ecopsychology 1 (2009): 8-13.

2. As Figley suggested, trauma psychology is a paradigm permitting "investigators and practitioners to understand the process by which people perceive adversity, react to it, recover to a resilient or growth state or to an unwanted state." See Robert W. Rieber, Encyclopedia of the History of Psychological Theories, Springer, 2012, p. 1137.

3. Here in environmental ethics, philosophers such as Thomas Aquinas (1225-1274), René Descartes (1596-1650), John Stuart Mill (1806-1873), John Locke (1632-1704), and Immanuel Kant (1724-1804), have been checked. Those philosophers, agreeing with that only humans deserve moral concern, are labeled "anthropocentric."

4. The cited Chinese is from Qu Yuan Ji Jiao Zhu, p. 16.

5. Ibid., p. 39.

6. Ibid., p. 160.

7. Ibid., p. 553.

8. It is well-known that the name of the Seven Sages of the Bamboo Grove originates from A New Account of Tales of the World, in chapter 23, "the seven used to gather beneath a bamboo grove, letting their fancy free in merry revelry. For this reason the world calls them the Seven Sages of the Bamboo Grove” (七人常集於竹林之下，肆意酣暢，故世謂“竹林七賢”《世說新 語·任誕第二十三》).

9. The cited Chinese is from Zhulin Qixian Shiwen Quanji Yizhu, p. 302.

10. The cited Chinese is from Zhulin Qixian Shiwen Quanji Yizhu, p. 190.

11. Ibid., p. 230.

12. Andrew L. March suggests that landscape is better than nature because the latter has the trouble of being suggestive and vague. See self and landscape in Su Shih, Journal of the American Oriental Society, 1966, Vol. 86, No. 4, pp. 377-96. Nature, Ziran, actually refers to different things in Chinese literature, such as inherent attribute of something, unintentional character of certain behavior, an undisturbed developing of a process, the environment that humans dwell in, the non-human world, and so on. March considers there is no Chinese term quite like landscape, and typical expression are "hills and waters." The corresponding Chinese words of "hills and waters" should be shanshui, but Chinese ancient sages know that shanshui are beyond "hills and waters." Alternatively, in other words, there is no English term quite like shanshui. In this article, I use "nature" to emphasize the non-human environment as human's spiritual dwelling place, which is beyond the sum of hills and waters, and becoming something else.

13. Although Qu Yuan is a failed example of self-healing from nature, he is vital to my later discussion about life and freedom.

14. In the newest research to $\mathrm{Li} \mathrm{Sao,} \mathrm{Gopal} \mathrm{Sukhu} \mathrm{writes} \mathrm{a} \mathrm{whole} \mathrm{chapter} \mathrm{to} \mathrm{explore} \mathrm{the} \mathrm{rhetorical} \mathrm{uses} \mathrm{of} \mathrm{plant} \mathrm{imaginary} \mathrm{in}$ the Warring States period works. The author thinks $\mathrm{Li}$ Sao, under this influence, uses the fragrant plant such as Lan to symbolize virtue and foulsmelling plants symbolizing vice and the corrupt. The worldview behind these symbolizing is connected with spirit descent and the conception of the cosmos that "the cosmos was interpenetrated and controlled by forces inhabiting an invisible dimension.” It is also in this sense that I think Qu Yuan divide natural world into two parts.

15. I am much appreciated in this view that an advice from the peer review points out "A landscape is NOT natural; it is human made. Buddhists, Daoist and even Confucians and others find comfort and some therapeutic release in nature itself."

16. Mencius, translated into English by Zhao Zhentao, Zhang Wenting, and Zhou Dingzhi, translated into modern Chinese by Yang Bojun, Hunan People’s Publishing House and Foreign Languages Press, 1999, p. 251. Comparatively, another translation is, "Humaneness, rightness, propriety, and wisdom are not infused into us from without. We definitely possess them." See, Mencius, translated by Irene Bloom, Columbia University Press, Reprint edition, 2009, p. 124. Christianity is so focused on the concept of original sin and totally treats the human body or flesh as bad. Confucianism is also sure on one thing, that is, the inherent goodness of life.

17. In his paper entitled "Tao Psychotherapy: Introducing a New Approach to Humanistic Practice,” Erik Craig brings Tao Psychotherapy to western academia, considering it as "a single coherent approach" combining psychoanalytic, existential, humanistic, and transpersonal perspectives. Interestingly in his paper he uses 10 ox herding figures from Chan/Zen Buddhism to demonstrate the process of Tao Psychotherapy, beginning with losing one's ox and trying to find it (pointing to neurosis anxiety, or "nuclear feeling," or "most intractable difficulties in life," as the inventor of this approach defined), through finding the ox and forgetting both the ox and self, at last ending up in a state one can enter the world with open hands (living a compassionate and 
altruistic life). In the 10 figure, there is landscape in nine of them and there is one with landscape (no ox, no human) only, but obviously the "world" in this paper is not so clear, at least it does emphasize the world metaphysically, but not ecologically. See The Humanistic Psychologist 35.2 (2007): 109-33.

18. CBC News, Filmmaker Rescued from Yukon Wilderness. <http://www.cbc.ca/news/canada/north/story/2009/08/28/ward le-yukon-survival-show.html>. (24 May, 2013).

19. Ibid.

20. Xie Yangju carries out one research concerning this topic. Seeing that some scholars view Zhuangzi as a liberal, he compared the concept of "freedom" in west sense and "Xiaoyao" in Zhuangzi, and he deems that it is improper to label "liberal" to Zhuangzi. "Freedom," the core of modern west political science, emerged in the setting of human-nature and subject-object dichotomy, however "Xiaoyao" aspires people to dispel human-nature and subject-object dichotomy, to commune with nature and the universe.

\section{Works Cited}

CBC News, “Filmmaker Rescued from Yukon Wilderness.” 24 May, 2013. <http://www.cbc.ca/news/canada/north/story/2009/08 /28/wardle-yukon-survival-show.html>.

Chen Jo-Shui, and Liu Tsung-yuan. Intellectual Change in T'ang China. NY: Cambridge University Press, 1992. 773-819.

Craig, Erik. “Tao Psychotherapy: Introducing A New Approach to Humanistic Practice.” The Humanistic Psychologist 35.2 (2007): 109-33.

Elvin, Mark. The Retreat of the Elephants. An Environmental History of China. New Haven and London: Yale University Press, 2004.

Ge, Xiaoyin. “On the Attention of Li in Su Shi’s Poet and Prose.” Academic Monthly (CHN) 4(1995): 82-87.

Geping, Han. Zhulin Qixian Shiwen Quanji Yizhu. Changchun: Jilin Literature and History Publishing, 1997.

Guo, Xiwei. “On Political Attitude of Wei-Jin Scholars by the Seven Sages of the Bamboo Grove.” Journal of Literature, History and Philosophy (CHN) 1 (1992): 25-29.

Kaicheng, Jin, Dong Hongli, and Gao Luming. Qu Yuan Ji Jiao Zhu. Beijing: Zhonghua Shuju, 1996.

Laozi, Moss Roberts. "Dao De Jing.” The Book of the Way. Trans. Berkeley and Los Angeles. Ca: University of California Press, 2004. 106-18.

Leopold, Aldo. A Sand County Almanac: With Essays on Conservation. NY: Oxford University Press, Reprinted edition, 2001.

Liu, Lee. “Made in China: Cancer Villages.” Environment 52 (2010): 1-21.

Liu Zongyuan. Liu Zongyuan Ji. Beijing: Zhonghua Shuju, 1979.

Louv, Richard. Last Child in the Woods. Chapel Hill. NC: Algonquin Books of Chapel Hill, revised and updated edition, 2008.

Lovelock, James. Gaia: A New Look at Life on Earth. NY: Oxford University Press, reissued edition, 2000.

March, Andrew L.. Self and Landscape in Su Shih, Journal of the American Oriental Society 86.4 (1966): 377-96.

May, Rollo. The Psychological Bases of Freedom, Pastoral Psychology 13.6 (1962): 41-46.

Irene Bloom, and Mencius. Menzi. NY: Columbia University Press, reprint edition, 2009.

Menzi, translated English by Zhao Zhentao, Zhang Wenting, Zhou Dingzhi, translated into modern Chinese by Yang Bojun, Mencius. Changsha: Hunan People’s Publishing House and Foreign Languages Press, 1999.

Milton, Martin. “Waking up to Nature: Exploring a New Direction for Psychological Practice.” Ecopsychology 1 (2009): 8-13.

Minford, John, and Joseph Shiu-ming Lau, eds. Classical Chinese Literature: An Anthology of Translations Vol. 1. NY: Columbia University Press and the Chinese University of Hong Kong, 2000.

Qu Yuan, et al., translated, annotated and introduced by David Hawkes, The Songs of the South (An Anthology of Qu, Yuan and other poets). London: Penguin Books, 1985.

Rieber, Robert W.. Encyclopedia of the History of Psychological Theories. Germany: Springer, 2012.

Rolston, Holmes. Philosophy Gone Wild. 1st ed. NY: Prometheus Books, 1989.

Roszak, Theodore, Mary E. Gomes, and Allen D. Kanner. Ecopsychology: Restoring the Earth, Healing the Mind. NY: Sierra Club Books, 1995.

Rousseau, Jean-Jacques. Reveries of the Solitary Walker. NY: Oxford University Press, 2011.

Shane, Estelle. “Approaching Termination: Ideal Criteria Versus Working Realities.” Psychoanalytic Inquiry 29 (2009): 167-73.

Su Shi, collected and annotated by Wang Wengao. Su Shi Shi Ji. Beijing: Zhong Hua Shu Ju, 1982.

Su, Shi. Selected Poems of Su Shi. Changsha: Hunan People’s Publishing House, 2007. 
Sukhu, Gopal. The Shaman and the Heresiarch: A New Interpretation of the Li sao. NY: State University of New York Press, 2012.

The Editorial Committee of Chinese Civilization. China: Five Thousand Years of History and Civilization. Hong Kong: City University of Hong Kong, 2007.

Weiner, Irving B., and Robert F. Bornstein. Principles of Psychotherapy: Promoting Evidence-based Psychodynamic Practice, 3rd ed. NJ: John Wiley \& Sons, Inc., 2009.

Yangju, Xie. "Xiaoyao and Freedom: A Case Analysis of Interpreting Chinese Philosophy With Western Conception." Philosophical Studies (CHN) 2 (2004): 34-40.

Zhu Danqiong, and Li Yuan. "The Inner Ego and External Nature: On the Implication of Su Shi's Works to Environmental Philosophy.” Economic and Social Development (CHN) 9 (2011): 126-31.

Zhu, Jinghua. "The Spiritual Insight From Heaven and Earth: An Assessment on Su Shi’s Life in Lingnan and Hainan.” The New Orient (CHN) 6 (1996): 34-41. 